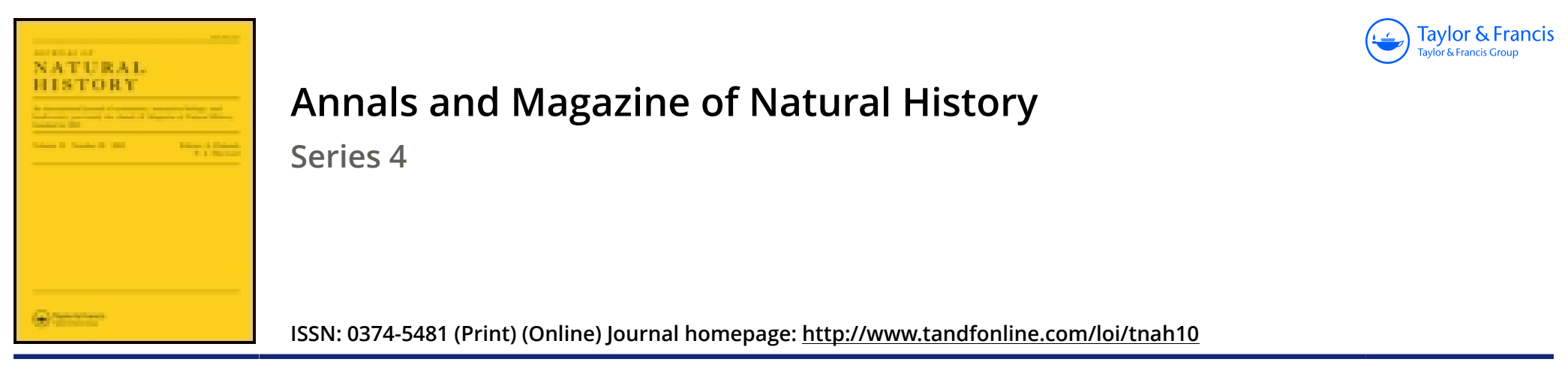

\title{
LVIII._Additions to the Australian Curculionidæ. Part VII
}

\section{Francis P. Pascoe F.L.S.}

To cite this article: Francis P. Pascoe F.L.S. (1874) LVIII._Additions to the Australian Curculionidæ. Part VII, Annals and Magazine of Natural History, 13:78, 412-419, DOI: 10.1080/00222937408680896

To link to this article: http://dx.doi.org/10.1080/00222937408680896

央 Published online: 15 Oct 2009.

Submit your article to this journal $\sqsubset \pi$

Џll Article views: 5

Q View related articles $₫$ 
LVIII.-Additions to the Australian Curculionidæ. Part VII. By Francis P. Pascoe, F.L.S. \&c.

\author{
Cruptorhynchings. \\ Psydestis, n. g. \\ affluens. \\ Poropterus tetricus. \\ Scolyphrus, n. g. \\ - obesus. \\ Petosiris annulipes. \\ Drassicus infaustus. \\ Imaliodes scrofa. \\ Acalles delirus. \\ - nucleatus.
}

Acalles distans.

- cribricollis.

— bisignatus.

- perditus.

- memnonius.

_ foraminosus.

- expletus.

Euoropis, n. g.

- castanea.

Embaphiodes, n. g.

- pyxidatus.

\section{Psydestis.}

Rostrum breviusculum, cylindricum, validum, subarcuatum; scrobes submedianæ, ad oculos currentes. Oculi rotundati, tenuiter granulati, antice modice approximati. Scapus oculum attingens; funiculus 7-articulatus, articulis duobus basalibus longiusculis, cæteris brevibus; clava distincta. Prothorax transversus, utrinque ampliatus, basi bisinuatus, lobis ocularibus obsoletis. Elytra condata, convexa. Coxce anticæ hand contiguæ; femora crassa, dentata; tibice breves, compressæ, intus bisinuatæ, extus rectæ; tarsi articulo ultimo tenuato. Mesosternum depressum, valde transversum. Abdomen segmento secundo brevi.

Allied to Melanterius ; but differs in its short stout rostrum, absence of ocular lobes, and short second segment of the abdomen. There is also an evident affinity between this genus and Diethusa, Enide, and Lyboeba-genera referred by me to the Erirhininæ, from their apparent connexion with Gerynassa, Erytenna, \&c. ; but I think now that they will be better placed in the neighbourhood of Melanterius.

\section{Psydestis affluens.}

$P$. obovata, valde convexa, fusca, sat dense fulvo-squamosa, cinnamomeo plagiatim vel maculatim varia ; rostro capite sesquilongiore, apice rufescenti et leviter punctulato; antennis piceo-testaceis, clava infuscata; prothorace apice quam basi triplo angustiore, dorso bi- vel trinotato; elytris sulcatis, interstitiis carinatis, humeris obliquis, apicibus rotundatis. Long. $2 \frac{1}{3}$ lin.

Hab. West Australia.

\section{Poropterus tetricus.}

$P$. sat late ovatus, niger, fusco-squamosus ; capite inter oculos transverse depresso; rostro subbrevi, valido, punctis magnis raris (apice solo excepto) rude impresso; funiculo articulis duobus basalibus fere æqualibus; prothorace transverso, supra paulo depresso, apice integro, in medio canaliculato, utrinque angulato- 
producto, basi profunde bisinuato ; elytris modice convexis, ampliatis, apicem versus sat fortiter constrictis, apice ipso rotundato, supra irregulariter nigro-fasciculatis, squamis erectis elaviformibus adspersis ; abdomine segmentis duobus basalibus peramplis ; tarsis posticis articulo penultimo minus bilobo. Long. 6 lin.

$H a b$. Gayndah.

In outline like $P$. innominatus (antè, vol. xi. p. 197), but proportionally broader, the prothorax strongly and angularly expanded at the sides, the rostrum stout, comparatively short, and roughly punctured, and the two basal joints of the funicle of nearly equal size, the second perhaps a trifle longer. The fascicles on the elytra are disposed nearly as in $P$. innominatus, but are less distinctly limited.

\section{SCOLYPHRUS.}

Rostrum subrobustum, arcuatum; scrobes submedianæ, obliquæ, ampliatæ. Scapus in medio rostri insertus; funiculus 7-articulatus, articulis duobus basalibus longioribus, ultimo in clavam continuato. Prothorax ad latera compressus, supra parum convexus, apice productus. Elytra ampla. Femora parum incrassata, mutica; tibice rectæ; tarsi lineares, infra hand spongiosi. Abdomen segmentis duobus basalibus peramplis.

Differentiated from Poropterus by its narrow tarsi, the third joint not being bilobed, canaliculate beneath, with the edges fringed with silky hairs. Agenopus, also having linear tarsi, has the three intermediate segments of the abdomen equal or nearly so. The species described below is a rough-looking insect, with a deep prothorax, the sides below the line of the back compressed and nearly vertical.

\section{Scolyphrus obesus.}

S. niger, opacus, squamulis crassis griseis adspersus ; rostro prothorace breviore, sat sparse punctulato; oculis infra sensim angustioribus; funiculo articulo secundo quam primo longiore; clava parva; prothorace longitudine latitudini æquali, dorso in medio longitudinaliter depresso, apice angusto, ante medium fortiter rotundato, dein ad basin parum angustiore; elytris peramplis, late ovatis, sat fortiter convexis, basi grosse, versus medium sensim minus punctatis, apice rotundatis. Long. 8 lin.

Hab. Queensland (Port Denison).

\section{Petosiris annulipes.}

$P$. subovalis, supra modice convexus, fuscus, squamis erectis concoloribus vage adspersus; capite inter oculos longitudinaliter excavato ; rostro modice elongato ; antennis subferrugineis ; funiculo articulis duobus basalibus æqualibus, quatuor sequentibus breviusculis, ultimo ralde ampliato; prothorace transverso, lateribus a 
medio parallelis, supra tuberculis quatuor mediocribus transversim sitis; elytris subcordiformibus, humeris obliquis, tune ad medium parallelis, postice cito angustioribus, apice rotundatis, subseriatim fortiter punctato-impressis, interstitiis $3^{\circ}, 5^{\circ}, 7^{\circ}$ tuberculato-fasciculatis, basi utrinque callosis; femoribus tibiisque subalbido-annulatis, his minus elongatis. Long. 4 lin.

Hab. New South Wales (Armadale).

The elytra are longer and somewhat differently formed than in $P$. cordipennis, having coarsely impressed punctures, and with a marked callosity on each side at the base. The femora have two and the tibiæ one well-defined whitish ring on each of them respectively.

\section{Drassicus infaustus.}

$D$. sat late ovatus, niger, opacus, squamis concoloribus rude vestitus ; rostro rugoso-punetato ; antennis ferrugineis, apicem versus infuscatis; scapo brevi, pone medium rostri inserto; funiculo articulis duobus basalibus longitudine æqualibus; prothorace subtransverso, apice paulo producto, pone apicem vix constricto, in medio utrinque rotundato, modice confertim punctato ; elytris subgloboso-cordatis, basi prothorace haud latioribus, suleatopunctatis, interstitiis convexis, indistincte griseo-maculatis; femoribus infra mediocriter dentatis; tibiis brevibus. Long. $2 \frac{3}{4}$ lin.

Hab. Queensland (Wide Bay).

In the two normal species of Drassicus the apex of the prothorax forms a sort of hood over the head; in the above it is of the ordinary character; but although this and some minor points leave a sort of gap between them, there seems nothing of structural importance to show that they are not congeneric.

\section{Imaliodes scrofa.}

I. late ovatus, fuscus, omnino dense griseo-squamosus, supra squamis majoribus parce, infra pedibusque minus adspersus; rostro prothorace paulo breviore, apicem versus sensim minus squamoso; antennis subferrugineis ; funiculo articulis duobus basalibus longiusculis, $3^{\circ} 4^{\circ}$ gradatim brevioribus, tribus ultimis turbinatis ; clava distincta ; prothorace subtransverso, basi quam apice duplo latiore, bisinuato, in medio rotundato; elytris utrinque rotundatis, postice declivibus, sulcato-punetatis, insterstitiis alternis magis elevatis ; femoribus tibiisque modice incrassatis. Long. 4 lin.

Hab. Albany.

Differs from the normal forms in its longer rostrum, the pectoral canal terminating a little more between the intermediate coxæ, the club not closely connected to the funicle, and the legs less robust. In habit they are much alike. 


\section{Acalles delirus.}

$A$. ovalis, niger, opacus, supra squamis erectis adspersus; rostro antice punctis magnis in seriebus quatuor dispositis; antennis ferrugineis ; clava ovata, obtusa ; prothorace longitudine latitudini æquali, utrinque fortiter rotundato, pone apicem haud constricto, apice ipso angustissimo, supra rude foveato, interspatiis nitide granulatis, in medio linea elevata nitida instructo ; elytris prothorace haud latioribus, subseriatim rugoso-punctatis, interstitiis convexis, granulis nitidis, plurimis squamam albam emittentibus, obsitis ; tibiis aúicis haud, cæteris paulo compressis. Long. $2 \frac{3}{4}$ lin.

Hab. Rockhampton.

The species here referred to Acalles appear to me to differ in no respect generically from such of the European species as I have examined. They are all dark brown or black, with few scales; and these, arising singly from punctures, are frequently more or less erect and claviform or spatulate-common characters among the Cryptorhynchinæ. The rostrum is comparatively stout, as a rule perhaps a little shorter than the prothorax, and always very perceptibly broader towards the apex; the first two abdominal segments are large and pitted with very coarse punctures, each bearing a broad flat, or sometimes a narrow curved, scale. Curculio stupidus, Fab. (Ent. Syst. ii. p. 432), from the type in the British Museum, appears to be referable to Acalles; but its tibiæ are much longer than usual, and its posterior femora are toothed beneath; in other respects it is like $A$. bisignatus, but considerably larger. Curculio luridus, Fab. (Ent. Syst. ii. p. 431), placed in Acalles in the Munich Catalogue, is a Poropterus. Acalles obesus, Boisd. (Astrol. ii. p. 438, Tylodes), is probably not Australian: Boisduval gives no habitat; but I have it from Gagie and Ceram, where it was found by Mr. Wallace.

The following table will give an idea of the diagnostic characters of the species here described :-

Elytra granulate.

Rostrum punctured in four rows

Rostrum irregularly punctured.

Funicle scarcely longer than the scape ........... bisignatus.

Funicle twice as long as the scape $\ldots \ldots \ldots \ldots \ldots \ldots$ cribricollis,

Elytra not granulate.

Prothorax contracted behind the apex.

Base of elytra not or scarcely broader than the prothorax.

Rostrum more or less closely and coarsely punctured.

Rostrum less closely punctured towards the apex.

Prothorax finely punctured ................ perditus.

Prothorax coarsely punctured .................. foraminosus.

Rostrum very closely punctured throughout .... nucleatus.

Rostrum not closely or coarsely punctured ......... memnonius.

Base of the elytra manifestly broader than the prothorax distans.

Prothorax not contracted behind the apex $\ldots \ldots \ldots \ldots$ expletus. 


\section{Acalles nucleatus.}

A. ovatus, niger, opacus, squamis albidis adspersus; rostro valido, punctis majusculis, singulis squama minuta instructis, creberrime impresso; fronte capitis leviter punctata; antennis nitide ferrugineis ; funiculo in clavam continuato; prothorace modice transverso, ante medium magis rotundato, confertim fortiter punctato; elytris subcordatis, sulcato-punetatis, punctis foveiformibus, approximatis, interstitiis convexis, subangustis, leviter punctatis; tibiis brevibus, posticis vix longioribus. Long. $2 \frac{3}{4}$ lin.

Hab. Adelaide.

The rostrum is very closely and coarsely punctured even to the apex.

\section{Acalles distans.}

A. sat late ovatus, niger, subnitidus ; rostro punctis magnis irregulariter adsperso ; antennis nitide ferrugineis ; clava ovata, obtusa ; prothorace transverso, utrinque ampliato-rotundato, punctis mediocribus sat crebre impresso; elytris substriato-foveatis, foveis magnis, remotis, interstitiis subplanatis, granulis parvis depressis instructis; pedibus piceis; tibiis brevibus, compressis. Long. $2-2 \frac{1}{2}$ lin.

Hab. Swan River.

A broad species, almost elliptic in outline, with the elytra very obviously broader at the base than the prothorax. The rostrum in one of my specimens, owing to the irregularity of the punctuation at about the middle of its length, has three smooth oblong patches.

\section{Acalles cribricollis.}

$A$. ovatus, niger, subnitidus; rostro sublineatim sulcato-punctato, punctis oblongis, nonnullis confluentibus ; antennis subferrugineis ; funiculo quam scapo duplo longiore; prothorace subtransverso, crebre fortiter punctato, in singulis punctis squama elongata ; elytris cordatis, fortiter sulcato-punctatis, punctis ampliatis, singulis squama alba rotundata instructis, interstitiis modice convexis, granulis parvis uniseriatim obsitis; pedibus castaneis, sat vage punctatis; tibiis breviusculis. Long. $2 \frac{3}{4}$ lin.

Hat. Champion Bay.

The granules on the elytra are very small, but under a powerful lens very distinct; the punctures on the rostrum are mostly placed in grooves having smooth, slightly irregular lines between them.

\section{Acalles bisignatus.}

A. late ovalis, niger, opacus, squamulis griseis parvis adspersus ; 
rostro punctis magnis sat crebre irrorato; antennis subferrugineis, nitidis ; clava elongata acuminata ; prothorace transverso, utrinque valde ampliato-rotundato, apice fortiter constricto, subreticulatopunctato, in medio dorsi foveis duabus, transversim sitis, squamulis minutis albis repletis; elytris subcordatis, basi truncatis, ad angulos humerales dentato-projectis, suleato-foveatis, interstitiis irregulariter granulatis; abdomine segmentis duobus basalibus punctis permagnis, squamositate griseis indutis, notatis; tibiis vix compressis, magis, præsertim posticis, elongatis. Long. $3 \frac{2}{3}$ lin.

\section{Hab. Gayndah.}

Easily known from the other species here described by its prothorax marked with two shallow impressions or foveæ filled with white scales.

\section{Acalles perditus.}

A. ovatus, niger, vix nitidus, squamis albidis rarissime adspersus; capitis fronte tenuiter vage punctata; rostro sat grosse crebre, apicem versus subconfertim punctato; antennis subferrugineis, nitidis ; funiculo scapo fere longitudine æquali; clava breviter ovata; prothorace transverso, utrinque ante medium rotundato, apice constricto, - fortiter creberrime punctato ; elytris oblongocordatis, in medio quam prothorace latioribus, sulcato-foveatis, foreis modice approximatis, interstitiis convexis, leviter punctatis, maculis paucis albis, e squamis condensatis formatis, quarum duabus basalibns conspicue notatis, adspersis; tibiis, præsertim anticis intermediisque perbrevibus. Long. $2-2 \frac{1}{4}$ lin.

\section{Hab. Melbourne; Albany.}

The spots will probably be only found in fresh specimens.

\section{Acalles memnonius.}

A. ovatus, niger, subnitidus, rostro pedibusque castaneis, squamis albis rarissime adspersus; rostro breviusenlo, modice punctato, in medio lærigato; antennis subferrugineis; funiculo articulis nltimis valde transversis; clava ovata; prothorace longitudine latitudini æquali, pone apicem utrinque modice rotundato, grosse reticulato-punctato ; ely tris cordiformibus, sulcato-foveatis, foveis majuseulis, subquadratis, singulatim squama parva albida instructis; corpore infra pedibusque squamulis albis adspersis ; tibiis brevibus, haud compressis. Iong. $2 \frac{1}{4}-2 \frac{1}{2}$ lin.

\section{Hab. King George's Sound.}

This species is clearly differentiated by its rostrum, with oblong scattered punctures of intermediate size.

\section{Acalles foraminosus.}

$A$. ovatus, niger, nitidus, rostro basi capiteque grosse reticulato- 
punctatis, punctis versus apicem magis adsperso; antennis subferrugineis; funiculo quam seapo sesquilongiore; prothorace subtransverso fortissime crebre punctato, ad apicem punctis minoribus; elytris cordatis, fortiter sulcato-punctatis, punctis magnis subquadratis, interstitiis convexis, squamulis albis adpressis irroratis; corpore infra pedibusque squamulis albis elongatis adsperso; tibiis brevibus. Long. $2 \frac{1}{2}$ lin.

Hab. Albany.

Remarkable for the large, deep, and closely ranged punctuation of the prothorax.

\section{Acalles expletus.}

$A$. ovatus, fusco-piceus, griseo-squamosus ; rostro longiore, sat sparse punctulato, in medio lævigato; antennis subferrugineis, funiculo articulis longioribus; prothorace longitudine latitudini æquali, utrinque rotundato, apice haud constricto, grosse reticulatopunctato, in medio linea elevata instructo; elytris subcordatis, basi prothorace hand latioribus, squamis griseis adpressis sejunetim vestitis, sulcato-punctatis, interstitiis latis, convexis ; tibiis brevibus. Long. $2 \frac{1}{2}$ lin.

Hab. Rockhampton.

This species has a prothorax without any trace of the constriction behind the apex which is a character of most of the species of this extensive genus.

\section{EuORopis.}

$\mathrm{Ab}$ Acalle differt tibiis extus prope basin dente angulato instructis.

This character of the tibiæ is seen also in Empleurus and one or two other allied genera. It is perhaps of no great importance; but in a large genus like Acalles it is very desirable not to admit any species having a structural peculiarity at variance with its normal forms. The type of the genus is in habit like some of the preceding; but the sculpture is somewhat different:-small deep punctures on the prothorax, each filled with a white scale not rising above the surrounding level; and on the elytra fine punctured striæ, with flat, broad interstices, having only very fine traces of punctures.

\section{Euoropis castanea.}

$E$. ovata, subnitida, fusca, albo-squamosa, elytris pedibusque castaneis ; capite crebre punctulato ; rostro castaneo, basi longitudinaliter gibboso, sat dense squamoso, versus apicem vage punctulato; antennis subferrugineis ; scapo fere in medio rostri inserto; funiculo articulis duobus basalibus cæteris conjunctim paulo lon- 
gioribus; prothorace subconico, utrinque rotundato, punctis parvis, singulis squama repletis, confertim impresso; elytris subovatis, prothorace manifeste latioribus, basi fortiter bisinuatis, apice obtuse rotundatis, anguste striato-punctatis, striis squamulis piliformibus albis uniseriatim adpressis, interstitiis latis planatis, obsolete punctulatis; corpore infra, femoribus subtus tibiisque sat dense albo-squamosis, his brevibus, haud compressis, posticis paulo longioribus. Long. 3 lin.

Hab. Swan River.

\section{EMBAPHIODES.}

Rostrum tenuatum, paulo depressum, arcuatum; scrobes postmedianæ, ad oculum currentes. Oculi rotundati, subtenuiter granulati. Scapus oculum attingens; funiculus 7-articulatus, articulis quatuor primis elongatis, cæteris brevibus; clava oblonga, distincta. Prothorax subconicus, supra depressus, apice productus, lobis ocularibus prominulis. Scutellum parvum. Elytra cuneiformia, prothorace haud latiora, supra planata, margine exteriore carinata, epipleuris distinctis, verticalibus. Rima pectoralis inter coxas intermedias extensa, apice cavernosa. Pedes mediocres; femora postica elongata, subtus dentato-angulata, antica et intermedia mutica, sublinearia; tibice flexuosæ, compressæ; tarsi articulo basali modice elongato, penultimo fortiter bilobo. Abdomen segmentis duobus basalibus ampliatis.

A singular genus belonging to the Tylodes group, but, like its neighbours Plagiocorynus and Glochinorhinus, with no obvious allies. The upper surface of the narrow wedge-shaped elytra is slightly concave and bounded at the side, except towards the apex, by a very strong carina, from which the epipleura descends almost vertically; that it is not quite vertical is owing to a marked concavity below the carina; the epipleura itself constitutes the largest part of each elytron. Although this style is common among the Tenebrionidæ, I do not recollect any other instance of it among the Curculionidæ, except, to a certain extent, in Hybomorphus and a few others.

\section{Embaphiodes pyxidatus.}

$E$. fuscus, sordide griseo-squamosus; rostro quam capite prothoraceque conjunctim longiore, nitide castaneo, (basi excepta) esquamoso; antennis nitidis, funiculo articulo secundo quam primo sesquilongiore; prothorace pone apicem lunato-impresso, utrinque rotundato, erebre punctato, punctis singulis squamam gerentibus; elytris sejunctim squamosis, punctis squamigeris instructis, in dorso singulorum seriebus quatuor dispositis ; corpore infra pedibusque dense squamulosis, squamis majoribus dispersis. Long. 4 lin.

Hab. Lord Howe Island. 